PALEO

Revue d'archéologie préhistorique

29 | 2018

Varia

\title{
Harold Lewis DIBBLE
}

(1951-2018)

Alain Turq et Michel Lenoir

\section{CpenEdition}

Journals

Édition électronique

URL : http://journals.openedition.org/paleo/3708

DOI : $10.4000 /$ paleo.3708

ISSN : 2101-0420

Éditeur

SAMRA

\section{Édition imprimée}

Date de publication : 30 décembre 2018

Pagination : 11-22

ISSN : $1145-3370$

Référence électronique

Alain Turq et Michel Lenoir, « Harold Lewis DIBBLE », PALEO [En ligne], 29 | 2018, mis en ligne le 15 janvier 2020, consulté le 07 juillet 2020. URL : http://journals.openedition.org/paleo/3708 ; DOI : https://doi.org/10.4000/paleo.3708

\section{(ब) $\odot \Theta$}

PALEO est mis à disposition selon les termes de la licence Creative Commons Attribution - Pas d'Utilisation Commerciale - Pas de Modification 4.0 International. 


\section{Harold Lewis DIBBLE (1951-2018)}

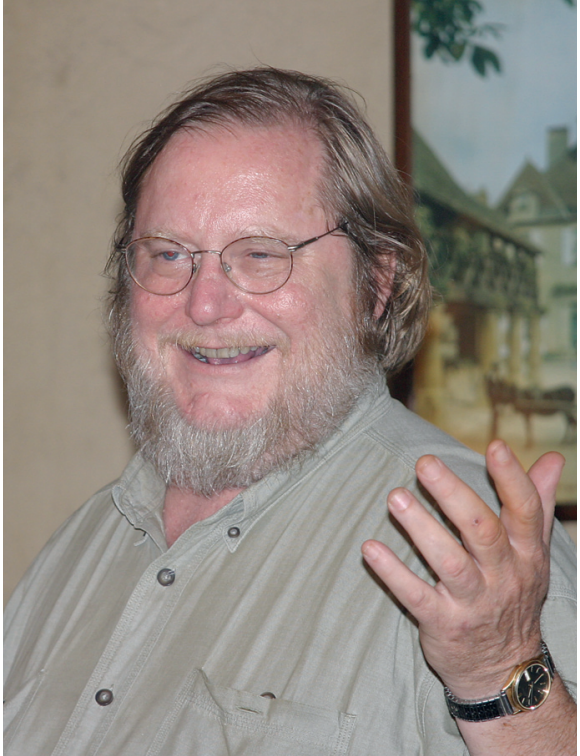

Harold

Année après année, au mois de juin, Harold Dibble arrivait en Périgord, dans sa maison de Carsac, pour fouiller, expérimenter ou préparer des publications. Pendant un ou deux mois, ses éclats de rire ponctuaient ses propos, son humour égayait les journées.

En 2018, la maison est restée désespérément silencieuse et vide. Harold Dibble était décédé à Philadelphie, à 67 ans, quelques jours avant son départ programmé pour la France. Pour ses collègues et amis, ce fut la fin des années de collaboration passées ensemble sur les gisements (Combe-Capelle, le Roc de Marsal, La Ferrassie), en réunion, discussion, partage que ce soit à Montferrand ou à Carsac venaient brutalement de s'arrêter.

Harold, était né en Californie et avait fait ses études à l'Université d'Arizona auprès du professeur Arthur Jelinek. Simultanément, il a participé aux fouilles au Pech de l'Azé IV et a fréquenté l'Institut du Quaternaire de l'Université de Bordeaux. Ainsi il découvrit la France et fit la connaissance du professeur François Bordes. Ce fut un tournant dans sa vie. Sans être son élève, il est devenu l'un de ses plus fidèles disciples, celui qui publia avec A. Debénath une version anglaise de sa méthode d'étude des industries lithiques. Après la mort du maître, il fut l'ami de D. de Sonneville-Bordes son épouse et poursuivit ses recherches avec plusieurs autres élèves. Ce profond attachement à l'Université de Bordeaux l'a amené à être, pendant un an, professeur associé à l'Université de Bordeaux et plus récemment, lors des inondations qui ont frappé les réserves du laboratoire PACEA il vint avec toute son équipe de fouille aider au nettoyage. Belle preuve de solidarité et de reconnaissance envers cette structure où de nombreux étudiants américains ont été accueillis.

En fait, Harold, le citoyen américain aux lointaines origines nordiques, était devenu, au fil des ans, périgourdin, attaché aux paysages, aux traditions, aux habitants et à la cuisine au point de confectionner avec bonheur certaines recettes.

Durant toute sa vie, la modernisation et l'amélioration des méthodes de fouille ont hanté Harold Dibble. Dès le milieu des années 1980, il introduisit, d'abord sur les chantiers de fouille de La Quina et Combe-Capelle, le théodolite laser. Avec son élève Shannon McPherron, il mit au point des logiciels informatiques de traitement des informations de terrain et d'étude du matériel lithique, logiciels mis gracieusement à la disposition des collègues qui le souhaitaient. Cette avancée a bouleversé et amélioré les méthodes de fouille, donné une place importante à la topographie et ouvert la voie à l'informatisation systématique des données aujourd'hui de mise.

Aller toujours plus loin dans ce domaine a été l'une de ses obsessions. Lorsque les techniques de terrain ne permettaient pas de découvrir l'histoire du dépôt comme, par exemple, dans le cas de la couche foyère de la base de la séquence du Pech de l'Azé IV, il préférait interrompre l'opération. II n'abandonnait pas, il s'arrêtait pour réfléchir, trouver une solution et reprenait le travail. Ainsi sur ce site, treize ans plus tard il a engagé sur la même couche (couche 8) une nouvelle opération avec une méthodologie qui lui paraissait mieux appropriée : prélever des blocs de la couche et les fouiller en laboratoire, sous la loupe binoculaire, avec toute une équipe de spécialistes. Souhaitons que cette expérience puisse être menée à son terme, pour pouvoir juger du bien-fondé de cette tentative. 
Le nom d'Harold restera à jamais lié à celui de l'homme de Néandertal. Ses nombreux travaux de terrain, ses multiples études sur le Paléolithique moyen du Proche-Orient, de l'Égypte et de l'Europe occidentale, le grand nombre d'analyses de séries archéologiques et le volet expérimental de sa recherche ont fait de lui l'un des meilleurs spécialistes du sujet. Professeur infatigable, à travers ses publications, l'organisation de plusieurs colloques, son enseignement, il a largement contribué à changer la vision que l'on avait de cette espèce humaine aujourd'hui disparue.

Sur le terrain pendant près de 40 ans, il eut avec son équipe une importante activité en France (Combe-Capelle, 1987-1990 avec M. Lenoir ; Cagny-l'Epinette, dans la Somme, avec A. Tuffreau, 1991-1994 ; Grotte de Fontéchevade, Charente, 1994-1998, avec A. Debénath ; Pech de l'Aze IV, 1999-2002 ; le Roc-de-Marsal, 2004-2010 et La Ferrassie, $2011-2016$ avec A. Turq ; La Gane à Groléjac en 2011 avec A. Morala) mais aussi en Égypte (prospection à Abydos, 2000-2007) et au Maroc (fouille avec A. Debénath de la grotte de Temara puis seul, de la grotte des Contrebandiers). La révision de tous ces sites accompagnée le plus souvent d'un réexamen des anciennes collections avec l'exploitation des carnets de fouilles, des plans, la publication rapide des résultats, a indéniablement apporté un plus à la connaissance du Paléolithique moyen.

Pour une meilleure compréhension des ensembles lithiques, Harold, a réalisé de nombreuses reproductions expérimentales avec le souci de contrôler des variables en travaillant sur des blocs de verre (matière très homogène). Ces travaux réalisés en laboratoire ont permis de mieux comprendre l'importance respective des paramètres entrant en action lors de la fracturation des roches (angle, pression...). II engagea aussi une étude prenant en compte le pourcentage du cortex pour estimer le nombre de blocs. Ces approches novatrices sont intéressantes mais restent encore à approfondir et à valider par de nouvelles expérimentations.

Parmi toutes les études conduites par Harold Dibble, la plus importante est celle qui faisait écho au débat entre François Bordes et Lewis Binford, et qui portait sur la réduction des racloirs. À la suite de G. Frison et d'Arthur Jelinek, elle le conduisit à proposer un nouveau mode d'interprétation sur la base des deux principales classes d'outils du Paléolithique moyen soumis à des analyses métriques afin de fournir une explication fondée sur le réavivage des outils dont l'intensité dépend de l'abondance et de la disponibilité de la matière première. II en est résulté une nouvelle approche des ensembles lithiques remettant, en partie, en question l'analyse typologique mais aussi morpho-technique de F. Bordes. Bien qu'au départ souvent critiquée, notamment en raison de son caractère trop systématique, elle a été en partie confirmée par les études technologiques plus récentes : les outils retouchés moustériens changeaient souvent de catégorie typologique, voire même de nature (redevenaient des nucléus) entre le moment de leur fabrication et celui de leur abandon. II avait ainsi touché du doigt l'une des spécificités des Néandertaliens,leur capacité d'adaptation, l'une de leurs caractéristiques qui a probablement permis à la lignée d'avoir une présence aussi longue dans notre histoire.

Sa rigueur scientifique et sa conviction qui voulait que cette lignée humaine était fondamentalement différente de la nôtre l'ont conduit vers un certaine forme de scepticisme. En ne voulant prendre en compte que des données avérées, en remettant en question les observations anciennes, il a remis en cause les comportements de cet homme vis-à-vis du feu, du traitement des morts ainsi que les conclusions émises par l'école française de technologie (les résultats d'un expérimentateur actuel ne peuvent être pris en compte pour des comparaisons avec des objets fabriqués par des Néandertaliens). Malgré ces divergences de vue, notre longue collaboration a pu se poursuivre en raison de l'accord total sur les observations de terrain et les données d'analyse. Les difficultés ne survenaient que dans la phase d'interprétation, donnant lieu à des débats infinis, animés, parfois véhéments mais toujours amicaux et cordiaux ou aucun n'arrivait à convaincre l'autre.

La renommée dont il jouissait de part et d'autre de l'Atlantique, reposait aussi sur son impressionnante capacité de travail. En une quarantaine d'année il publia 11 monographies (Combe-Capelle, Fontéchevade, Pech de l'Azé IV et préparait celle du Roc de Marsal, La Ferrassie...) et près de 200 articles. II a joué un rôle de responsabilité, consultant ou relecteur dans plusieurs revues ou instances scientifiques tant aux États-Unis (Journal of Paleolithic Archaeology, Proceedings of the National Academy of Science, PaleoAnthropology, Journal of Eurasian Prehistory, Nature, Journal of Archaeological Science, Science, National Science Foundation, Wenner-Gren Foundation, Leakey Foundation, National Geographic Society...) qu'en Europe (Préhistoire Européenne, Paleo).

Pendant les 22 ans durant lesquels Harold Lewis Dibble fut Professeur à l'Université de Pensylvannie, il forma de nombreux spécialistes de l'étude des industries lithiques qui ont essaimé en Amérique du Nord mais aussi dans le monde entier (Afrique du sud, Nouvelle-Zélande, Allemagne, Angleterre). Il fut également chercheur associé au Max Planck Institute for Evolutionary Anthropology (Leipzig, Germany)

Harold, excellait également dans un domaine important, celui de la recherche de crédits. II a obtenu le financement de 70 projets auprès de divers organismes et fondations : National Science Foundation, Leakey Foundation, University of Pennsylvania Research Foundation... Sans ce talent, la plupart des projets n'auraient pu voir le jour ou se dérouler dans d'aussi bonnes conditions.

Harold était un leader volontaire, déterminé, mais également plein de bonté, de finesse et d'humour. Pour tous les autres membres de ses équipes, ses collaborateurs, ce fut une véritable chance et un bonheur de travailler avec lui. Nous nous 
sommes tous nourris des échanges, des discussions et nous avons aussi pu apprécier une autre de ses qualités : la volonté de transmettre, d'enseigner, de partager. II s'impliquait beaucoup pour ses étudiants et il était toujours prêt à répondre favorablement aux demandes des uns et des autres. Ayant fait, à l'un d'entre nous, l'honneur et l'amitié de lui demander de rédiger la préface de la monographie du Pech de l'Aze IV (codirigée avec Shannon McPherron), il regretta, à la lecture du premier jet, que ce préfacier ne développe pas assez l'apport de François Bordes à la connaissance de ce gisement et les mette, lui et Shannon, trop en avant. II lui demanda donc de réduire la partie vantant leurs mérites et de développer ce qui revenait à leur prédécesseur, une belle preuve d'honnêteté scientifique que nous avons beaucoup appréciée.

Harold vécut intensément, trop sans doute, au détriment de sa santé.

Alain Turq et Michel Lenoir, ses vieux amis

Au revoir Yankee, le Frenchie te pleure mais compte bien te retrouver en paradis, et nous reprendrons là nos vives discussions matinales de Combe-Capelle, sur des sujets nous tenant pleinement à cœur et qui ont forgé ta renommée de préhistorien notamment la réduction des racloirs et la variabilité moustérienne (M.L.).

\section{Publications de Harold Dibble}

\section{I - Books, Monographs, CD-ROMs, and Graphic Texts}

\section{Books/Monographs}

2018 - Dibble, H. L., S. P. McPherron, P. Goldberg, and D. Sandgathe. The Middle Paleolithic Site of Pech de l'Azé IV. Springer International Publishing, Cave and Karst Systems of the World Series. XXIV, 236p.

2012 - El Hajraoui, M., R. Nespoulet, A. Debénath, and H. Dibble. Préhistoire de la Région de Rabat-Témara Villes et Sites Archéologiques du Maroc (V.E.S.A.M), Volume III. I'Institut National des Sciences de l'Archéologie et du Patrimoine, Rabat, Morocco.

2012 - Debénath, André and H. Dibble. Handbook of Paleolithic Typology Vol 1: The Lower and Middle Paleolithic of Europe. Translated into Korean and published by Sahoi Pyoungnon, Korea.

2009 - Chase, P., A. Debénath, H. Dibble, and S. McPherron. The Cave of Fontéchevade: Recent Excavations and Their Paleoanthropological Implications. Cambridge University Press. xviii+270 pp.

2003 - Soressi, M. and H. Dibble From Prehistoric Bifaces to Human Behavior: Multiple Approaches to the study of Bifacial Technologies. The University Museum, University of Pennsylvania.

1995 - Dibble, H. and O. Bar-Yosef. The Definition and Interpretation of Levallois Variability. Prehistory Press, Madison. xiii + 502 pp.

1995 - Dibble, H. and M. Lenoir. The Middle Paleolithic Site of Combe-Capelle Bas (France). University Museum Press, University of Pennsylvania. xviii+363 pp.

1994 - Debénath, André and H. Dibble. Handbook of Paleolithic Typology Vol 1: The Lower and Middle Paleolithic of Europe. The University Museum, University of Pennsylvania. ix $+202 p$.
1993 - Olszewski, Deborah and H. Dibble, editors. The Paleolithic Prehistory of the Zagros-Taurus. The University Museum, University of Pennsylvania. $x+236 p$.

1992 - Dibble, H. and Paul Mellars, editors. The Middle Paleolithic: Adaptation, Behavior, and Variability. The University Museum,University of Pennsylvania. Museum Symposium Series Vol 2. $x+216$ pp.

1988 - Dibble, H. and A. Montet-White, editors. Upper Pleistocene Prehistory of Western Eurasia. University Museum Monograph 54, University Museum Symposium Series, Vol. 1, Philadelphia. xvi + 461 pp.

\section{Textbooks}

2015 - Sandgathe, D., H. Dibble, P. Goldberg, and S. McPherron. The Neanderthal Child of Roc de Marsal: $A$ Prehistoric Mystery, 2nd Edition. Pearson Learning Solutions.

2013 - Sandgathe, D., H. Dibble, P. Goldberg, and S. McPherron. The Neanderthal Child of Roc de Marsal: $A$ Prehistoric Mystery. Pearson Learning Solutions.

2003 - Dibble, H., S. McPherron, and B. Roth. Virtual Dig: A Simulated Archaeological Excavation of a Middle Paleolithic Site in France. Second Edition. McGraw-Hill Higher Education, Calif. xiii+144 (workbook/text) and CD-ROM.

2002 - McPherron, S. and H. Dibble. Using Computers in Archaeology: A Practical Guide. McGraw-Hill Mayfield, Boston, $x v i+254$ pp.

1999 - Dibble, H., S. McPherron, and B. Roth. Virtual Dig: A Simulated Archaeological Excavation of a Middle Paleolithic Site in France. Mayfield Press, Mountain View, Calif. ix+148 (workbook/text) and CD-ROM.

\section{CD-Rom}

1996 - Dibble, H. and S. McPherron. Combe-Capelle on CD-ROM: A Multimedia Companion to The Middle Paleolithic Site of Combe-Capelle Bas (France). University Museum Press, University of Pennsylvania. 


\section{Other}

2003 - Dibble, H. The Human Evolution Cookbook. The University Museum, University of Pennsylvania.

\section{II - Journal Articles, Book Chapters, and Other Publications (not including papers/posters)}

Submitted - Dibble, H., S. Lin, D. Sandgathe, and A. Turq. The Making of an Archaeological Collection: An Example from La Ferrassie. Journal of Paleolithic Archaeology.

Submitted - Wroth, K., D. Cabanes, J. Marston, V. Aldeias, D. Sandgathe, A. Turq, P. Goldberg, and H. Dibble. Neanderthal Plant Use and Pyrotechnology: Phytolith Analysis at Roc de Marsal, France. Archaeological and Anthropological Sciences.

2018g - Rezek, Z., Dibble, H., McPherron, S., Braun, D., and Lin, S. Two million years of flaking stone and the evolutionary efficiency of stone tool technology. Nature Ecology and Evolution 2018. doi.org/10.1038/s41559-0180488-4.

2018f - Dibble, H. L., D. Sandgathe, P. Goldberg, S. P. McPherron, V. Aldeias Were European Neandertals Able to Make Fire? Journal of Paleolithic Archaeology (2018): 126.

2018e - Sandgathe, D., H. Dibble, S. J. P. McPherron, and P. Goldberg. Introduction. In Dibble, H. L., S. P. McPherron, P. Goldberg, and D. Sandgathe, The Middle Paleolithic Site of Pech de l'Azé IV., pp. 1-19. Springer, Cave and Karst Systems of the World Series.

2018d - Goldberg, P., S. P. McPherron, H. Dibble, and D. Sandgathe. Stratigraphy, Deposits, and Site Formation. In Dibble, H. L., S. P. McPherron, P. Goldberg, and D. Sandgathe, The Middle Paleolithic Site of Pech de l'Azé IV., p. 21-74. Springer, Cave and Karst Systems of the World Series, pp. 21-74.

2018c - McPherron, S. P., H. L. Dibble, D. Sandgathe, and P. Goldberg, with contributions by S. Lin and A. Turq. The Lithic Assemblages. In Dibble, H. L., S. P. McPherron, P. Goldberg, and D. Sandgathe, The Middle Paleolithic Site of Pech de l'Azé IV., pp. 117-219. Springer, Cave and Karst Systems of the World Series.

2018b - Dibble, H. L., S. J. P. McPherron, P. Goldberg, and D. Sandgathe. Summary and Conclusions. In Dibble, $\mathrm{H}$. L., S. P. McPherron, P. Goldberg, and D. Sandgathe, The Middle Paleolithic Site of Pech de l'Azé IV., pp. 221-227. Springer, Cave and Karst Systems of the World Series.

2018a - Dibble, H. L. and S. P. McPherron. Preface. In Dibble, H. L., S. P. McPherron, P. Goldberg, and D. Sandgathe, The Middle Paleolithic Site of Pech de l'Azé IV., pp. I-XXIV. Springer, Cave and Karst Systems of the World Series. 2017g - Richter, D., H. Dibble, S. McPherron, P. Goldberg, D. Sandgathe. Additional chronometric data for the small flake assemblages ('Asinipodian') from Pech de l'Azé IV (France) and a comparison with similar assemblages at the nearby site of Roc de Marsal. In, Vocation préhistoire. Hommage à Jean-Marie Le Tensorer, Wojtczak D, AI Najiar $M$, Jagher R, Elsuede $H$, Wegmüller $F$, and Otte $M$ (eds). Études et Récherches archéologiques de I Université de Liège 148.

2017f - Lin, Sam C., Z. Rezek, and H. L. Dibble. Experimental Design and Experimental Inference in Stone Artifact Archaeology. Journal of Archaeological Method and Theory (2017):1-26..

2017e - Leader, G., A. Abdolahzadeh, S. C. Lin, and H. L. Dibble. The Effects of Platform Beveling on Flake Variation. Journal of Archaeological Science Reports 16:213-223.

2017d - Dibble, H., A. Abdolahzadeh, V. Aldeias, P. Goldberg, S. McPherron, D. Sandgathe. How did Hominins Adapt to Ice Age Europe without Fire? Special volume on Fire and the Genus Homo, edited by D. Sandgathe and F. Berna. Current Anthropology 58, Supplement 16:S278-S287.

2017c - Richards, M., S McPherron, M. Pellegrini, L. Niven, $\mathrm{O}$. Nehlich, H. Dibble, A. Turq. Temporal variations in Equus tooth isotope values $(\mathrm{C}, \mathrm{N}, \mathrm{O})$ from the Middle Palaeolithic site of Combe Grenal, France (ca. 150,000 to 50,000 BP). Journal of Archaeological Science: Reports 14:189-198.

2017b - Frouin M., Guérin, G., Lahaye, C., Mercier, N., Huot, S., Aldeias, V., Bruxelles, L., Chiotti, L., Dibble, H., Goldberg, P., McPherron, S., Sandgathe, D., Turq, A. New luminescence dating results based on polymineral fine grains from the Middle and Upper Palaeolithic site of La Ferrassie (Dordogne, SW France). Quaternary Geochronology.

2017a - Sandgathe, D. and H. Dibble. Who Started the First Fire? Sapiens.org, 26 January 2017. http://www.sapiens.org/archaeology/neanderthal-fire/

2016j - Castel J.-C., Discamps, E., Sandgathe, D., Soulier M.-C., Dibble, H. L., Goldberg, P., McPherron S. P., Turq A. Neandertal subsistence strategies during the Quina Mousterian at Roc de Marsal (France). Quaternary International 436: 114-128.

2016i - Dibble, H. André Debénath (1940-2016). Bulletin de la Société Archéologicque et Historique de la Charente 2016 : 40-44.

2016h - Morala, André, and H. Dibble. «Groléjac. La Gane.» Archéologie de la France-Informations. une revue Gallia.

2016g - Rezek, Z., S. C. Lin, and H. Dibble. An Overview of Controlled Experiments in Flake Formation. In Olszewski, D. and A. Sullivan (editors), Archaeological Variability and Interpretation in Global Perspective, $\mathrm{p}$. 33-66. University Press of Colorado and Utah State University Press. 
2016f - Guérin, G., Frouin, M., Tuquoi, J., Thomsen, K., Goldberg, P. Aldeias, V, Lahaye, C., Mercier, N., Guibert, P., Jain, M., Sandgathe, D., McPherron, S., Turq, A., and Dibble, $\mathrm{H}$. The complementarity of luminescence dating methods illustrated on the Mousterian sequence of the Roc de Marsal: A series of reindeer-dominated, Quina Mousterian layers dated to MIS 3. Quaternary International (2016):1-14.

2016e - Dibble, H., Holdaway, S., Braun, D., Douglass, M., lovita, R., Lin, S., McPherron, S., Olszewski, D., and Sandgathe, D. Major Fallacies Surrounding Stone Artifacts and Assemblages. Journal of Archaeological Method and Theory (2016):1-39.

2016d - Hodgkins J., C. W. Marean, A. Turq, D. Sandgathe, S. P. McPherron, H. L. Dibble. Climate-mediated shifts in Neandertal subsistence behaviors at Pech IV and Roc de Marsal (Dordogne Valley, France). Journal of Human Evolution 96:1-18.

2016c - Jacobs, Z, Jankowski, N., Dibble, H. L., Goldberg, S. P. McPherron, D. Sandgathe, and Soressi, M. The age of three Middle Palaeolithic sites: single-grain optically stimulated luminescence (OSL) chronologies for Pech de l'Azé I, II, and IV (France). Journal of Human Evolution 95:80-103.

2016b - Lin, S., C. Pop, H. Dibble, W. Archer, D. Desta, M. Weiss, S. McPherron. The lack of effect of original stone size and reduction intensity on flake debris size distribution in lithic assemblages. American Antiquity 81(3):562-575.

2016a - Aldeias, V. H. L. Dibble, D. Sandgathe, P. Goldberg, S. J. P. McPherron. How heat alters underlying deposits and implications for archaeological fire features: a controlled experiment. Journal of Archaeological Science 67:64-79.

2015b - Guérin, G., M. Frouin, S. Talamo, V. Aldeias, L. Bruxelles, L. Chiotti, H. L. Dibble, P. Goldberg, J.-J. Hublin, M. Jain, C. Lahaye, S. Madelaine, B. Maureille, S. P. McPherron, N. Mercier, A. S. Murray, D. Sandgathe, T. E. Steele, K. J. Thomsen, A. Turq. A Multi-method Luminescence Dating of the Palaeolithic Sequence of $\mathrm{La}$ Ferrassie Based on New Excavations Adjacent to the La Ferrassie 1 and 2 Skeletons. Journal of Human Evolution 58:147-166.

2015a - Lin, S., S. P. McPherron, H. L. Dibble. Establishing Statistical Confidence in Cortex Ratios within and among Lithic Assemblages: A Case Study of the Middle Paleolithic of southwestern France. Journal of Archaeological Science 59:89-109.

2014c - Aldeias, V., P. Goldberg, H. Dibble, F. Berna, M. ElHajraoui. Deciphering Site Formation Processes through Micromorphological Observations at Contrebandiers Cave, Morocco. Journal of Human Evolution 69:8-30. 2014b - Dibble, H. L., V. Aldeias, P. Goldberg, S. P. McPherron, D. Sandgathe, and T. E. Steele. A Critical Look at Evidence from La Chapelle-aux-Saints Supporting an Intentional Neandertal Burial. Journal of Archaeological Science 53:649-657.

2014a - Magnani, M., Z. Rezek, S. C. Lin, A. Chan, and H. L. Dibble. Flake Variation in Relation to the Application of Force. Journal of Archaeological Science 46:37-49.

2013e - Goldberg, P., V. Aldeias, H. Dibble, S. McPherron, D. Sandgathe, and A. Turq. Testing the Roc de Marsal Neandertal "Burial" with Geoarchaeology. Archaeological and Anthropological Sciences 2013: 1-11.

2013d - Lin, S. C., Z. Rezek, D. Braun, and H. L. Dibble On the Utility and Economization of Unretouched Flakes: The Effects of Exterior Platform Angle and Platform Depth. American Antiquity 78(4): 724-745.

2013c - Richter, D., H. Dibble, P. Goldberg, S. McPherron, L. Niven, D. Sandgathe, S. Talamo, A. Turq. The Late Middle Palaeolithic in Southwest France: New TL data for the sequence of Pech de l'Azé IV. Quaternary International 294:160-167.

2013b - Dibble H., V. Aldeias, Z. Jacobs, D. Olszewski, Z. Rezek, S. Lin, E. Alvarez-Fernández, C. BarshaySzmidt, E. Hallett-Desguez, D. Reed, K. Reed, D. Richter, T. Steele, A. Skinner, B. Blackwell, E. Doronicheva, and M. El-Hajraoui. On the Industrial Affiliations of the Aterian and Mousterian of the Maghreb. Journal of Human Evolution 64:194-210.

2013a - Adelsberger, K., J. R. Smith, S. P. McPherron, H. L.Dibble, D. I. Olszewski, U. A. Schurmans, L. Chiotti. Desert Pavement Disturbance and Artifact Taphonomy: A Case Study from the Eastern Libyan Plateau, Egypt. Geoarchaeology 28:112-130.

2012n - El Hajraoui, M. A., R. Nespoulet, A. Debénath and H. Dibble. Perspectives. In El Hajraoui, M., R. Nespoulet, A. Debénath, and $\mathrm{H}$. Dibble. Préhistoire de la Région de Rabat-Témara. Villes et Sites Archéologiques du Maroc (V.E.S.A.M), Volume III. I'Institut National des Sciences de l'Archéologie et du Patrimoine, Rabat, Morocco, p. 269-270.

2012m - El Hajraoui, M. A., R. Nespoulet, A. Debénath and $\mathrm{H}$. Dibble. Conclusion Générale. In El Hajraoui, M., R. Nespoulet, A. Debénath, and H. Dibble. Préhistoire de la Région de Ra bat-Témara. Villes et Sites Archéologiques du Maroc (V.E.S.A.M), Volume III. I'Institut National des Sciences de l'Archéologie et du Patrimoine, Rabat, Morocco, p. 267-268.

2012I - Dibble, H., M. A. El Hajraoui, D. Olszewski. Les Industries Lithiques. In El Hajraoui, M., R. Nespoulet, A. Debénath, and $\mathrm{H}$. Dibble. Préhistoire de la Région de Rabat-Témara. Villes et Sites Archéologiques du Maroc (V.E.S.A.M), Volume III. I'Institut National des Sciences de l'Archéologie et du Patrimoine, Rabat, Morocco, p. 253-263 
2012k - El Hajraoui, M. A., R. Nespoulet, A. Debénath and H. Dibble. Naissance du Projet. In El Hajraoui, M., R. Nespoulet, A. Debénath, and H. Dibble. Préhistoire de la Région de Rabat-Témara. Villes et Sites Archéologiques du Maroc (V.E.S.A.M), Volume III. I'Institut National des Sciences de l'Archéologie et du Patrimoine, Rabat, Morocco, pp. 20-23.

2012j - El Hajraoui, M. A. , A. Debénath, R. Nespoulet and H. Dibble. Introduction Générale. In El Hajraoui, M., R. Nespoulet, A. Debénath, and H. Dibble. Préhistoire de la Région de Rabat-Témara. Villes et Sites Archéologiques du Maroc (V.E.S.A.M), Volume III. I'Institut National des Sciences de l'Archéologie et du Patrimoine, Rabat, Morocco, pp. 17-19.

2012i - El Hajraoui, M. A., A. Debénath, H. Dibble and R. Nespoulet. Avant-Propos. In El Hajraoui M., R. Nespoulet, A. Debénath and H. Dibble. Préhistoire de la Région de Rabat-Témara. Villes et Sites Archéologiques du Maroc (V.E.S.A.M), Volume III. I'Institut National des Sciences de l'Archéologie et du Patrimoine, Rabat, Morocco, p. 13-14.

2012h - Dibble, H., V. Aldeias, E. Alvarez-Fernández, B. Blackwell, E. Hallett-Desguez, Z. Jacobs, P. Goldberg, S. C. Lin, A. Morala, M. C. Meyer , D. I. Olzsewski, K. Reed, D. Reed, Z. Rezek, D. Richter, R. G. Roberts, D. Sandgathe, U. Schurmans, A. R. Skinner, T. E. Steele, M. El-Hajraoui. New Excavations at the Site of Contrebandiers Cave, Morocco. PaleoAnthropology 2012:145-201.

2012g - McPherron, S., H. Dibble, L. Chiotti, P. Chase, A. Debénath, and W. Farrand. Nouvelles données sur le Tayacien de Fontéchevade (Charente, France). L'Anthropologie 116 :321-347.

$2012 f$ - McPherron, S., H. Dibble, P. Goldberg, M. Lenoir, D. Turq «De Combe Grenal à Pech de l'Azé IV : l'évolution des méthodes de fouilles de François Bordes». In François Bordes et la Préhistoire. Actes du colloque de Bordeaux en 2009, pp. 65-77.

2012e - Guérin, G., E. Discamps, C. Lahaye, N. Mercier, P. Guibert, A. Turq, H. Dibble, S. McPherron, D. Sandgathe, P. Goldberg, M. Jain, K. Thomsen, M. Patou-Mathis, J.-C. Castel, M.-C. Soulier. Multi-method (TL and OSL), multi-material (quartz and flint) dating of the Mousterian site of the Roc 1 de Marsal (Dordogne, France) : correlating Neanderthals occupations with the climatic variability of 2 MIS 5-3. Journal of Archaeological Science 39:3071-3084.

2012d - McPherron, S., S. Talamo, P. Goldberg, L. Niven, D. Sandgathe, M. Richards, D. Richter, A. Turq, and H. Dibble. Radiocarbon Dates for the Late Middle Paleolithic at Pech de l'Azé IV, France. Journal of Human Evolution 39: 3436-3442. DOI: 10.1016/j.jas.2012.05.017 2012c - Turq A. H. Dibble, P. Goldberg, S. J.-P. McPherron, D. Sandgathe, N. Mercier, L. Bruxelles, D. Laville, S. Madelaine. Reprise des fouilles dans la partie ouest du gisement de la Ferrassie, Savignac-de-Miremont, Dordogne : problématique et premiers résultats. Quaternaire continental d'Aquitaine : un point sur les travaux récents, edited by P. Bertran and A. Lenoble. Quaternaire Continental d'Aquitaine, excursion AFEQ - ASF 2012: 78-87.

2012b - Aldeias V., F. Berna, H. Dibble, P. Goldberg, S. McPherron, D. Sandgathe, A. Turq. Evidence for Neandertal Use of Fire at Roc de Marsal (France). Journal of Archaeological Science 39:2414-2423.

2012a - Goldberg, P., H. Dibble, F. Berna, D. Sandgathe, S. McPherron, A. Turq. New Evidence on Neandertal Use of Fire: Examples from Roc de Marsal and Pech de l'Azé IV. Quaternary International 247: 325-340.

$2011 f$ - Turq, A., H. L. Dibble, P. Goldberg, McPherron, S., D. Sandgathe, H. Jones, K. Maddison, B. Maureille, S Mentzer, J. Rink, and A. Steenhuyse Les Fouilles Recentes du Pech de l'Azé IV (Dordogne). Gallia Préhistoire 53:1-70.

2011e - Sandgathe, D., H. Dibble, P. Goldberg, S. McPherron, A. Turq, L. Niven, and J. Hodgkins. On the Role of Fire in Neandertal Adaptations in Western Europe: Evidence from Pech de l'Azé IV and Roc de Marsal. PaleoAnthropology 2011:216-242.

2011d - Jacobs Z., M. C. Meyer, R. G. Roberts, H. Dibble, and M. A. El Hajraoui. Single-Grain OLS dating at Smugglers' Cave (Morocco): Improved Marine Isotope Stage 5 Age Constraints for the Middle Paleolithic Levels. Journal of Archaeological Science 38:3631-3643.

2011c - Sandgathe D.M., H.L. Dibble, P. Goldberg, S.P. McPherron, A. Turq, L. Niven, J. Hodgkins. Timing of the Appearance of Habitual Fire Use: Comments on Roebroeks and Villa» Proceedings of the National Academy of Science 108 (29): E298.

2011b - Sandgathe D., H. Dibble, P. Goldberg, S. McPherron. The Roc de Marsal Neandertal Child: A Reassessment of its Status as a Deliberate Burial. Journal of Human Evolution 61:243-253.

2011a - Rezek Z., S. Lin, R. lovita, and H. L. Dibble The Relative Effects of Core Surface Morphology on Flake Shape and other Attributes. Journal of Archaeological Science 38:1346-1359.

2010b - Olszewski D., H. Dibble, S. McPherron, U. Schurmans, Chiotti, L., and J. Smith. Nubian Complex Strategies in the Egyptian High Desert. Journal of Human Evolution 59:188-201.

2010a - Olszewski D., H. Dibble, U. Schurmans, S. McPherron, Chiotti, L., and J. Smith. "Middle Paleolithic Settlement Systems: Theoretical and Modeling Frameworks Using High Desert Survey Data From Abydos, Egypt." In Settlement Dynamics of the Middle Paleolithic and Middle Stone Age, Vol. III, Nicholas Conard and Anne Delagnes, editors. Kerns Verlag: Tübingen, pp. 81-101. 
2009j - Chiotti L., H. Dibble, D. Olszewski, S. McPherron, and U. Schurmans Middle Paleolithic Lithic Technology from the Western High Desert of Egypt. Journal of Field Archaeology 307-318.

2009i - Dibble H., F. Berna, P. Goldberg,S. McPherron, S. Mentzer, L. Niven, D. Richter, I. Théry-Parisot, D. Sandgathe, A. Turq A Preliminary Report on Pech de l'Azé IV, Layer 8 (Middle Paleolithic, France). PaleoAnthropology 2009:182-219.

2009h - Chiotti L., H. Dibble, S. McPherron, D. Olszewski, and U. Schurmans Prospections sur les plateaux désertiques du désert libyque égyptien (Abydos, Moyenne Egypte). Quelques exemples de technologies lithiques. L'Anthropologie 113 :341-355.

2009g - Dibble H., S. McPherron, D. Sandgathe, P. Goldberg, A. Turq, and M. Lenoir Context, Curation, and Bias: An Evaluation of the Middle Paleolithic Collections of Combe-Grenal (France). Journal of Archaeological Science 36:3540-3550

$2009 f$ - Dibble H. and Z. Rezek Introducing a New Experimental Design for Controlled Studies of Flake Formation: Results for Exterior Platform Angle, Platform Depth, Angle of Blow, Velocity, and Force. Journal of Archaeological Science 36:1945-1954.

2009e - Chase P., A. Debénath, H. Dibble, and $\mathrm{S}$. McPherron. "Summary and Conclusions". In Chase, P. et al. The Cave of Fontéchevade: Recent Excavations and Their Paleoanthropological Implications. Cambridge University Press, pp. 248-254.

2009d - Chase P., A. Debénath, H. Dibble, and $\mathrm{S}$. McPherron. "Processes of site Formation and their Implications." In Chase, P. et al. The Cave of Fontéchevade: Recent Excavations and Their Paleoanthropological Implications. Cambridge University Press, pp. 229-247.

2009c - Dibble H. and S. McPherron. "Description of the Lithic Industries." In Chase, P. et al. The Cave of Fontéchevade: Recent Excavations and Their Paleoanthropological Implications. Cambridge University Press, p. 170-226.

2009b - Chase P., A. Debénath, H. Dibble, and S. McPherron. "Introduction to the 1994-1998 Excavations". In Chase, P. et al. The Cave of Fontéchevade: Recent Excavations and Their Paleoanthropological Implications. Cambridge University Press, pp. 28-59.

2009a - Chase, P., A. Debénath, H. Dibble, and S. McPherron. "Introduction and Background". In Chase P. et al, The Cave of Fontéchevade: Recent Excavations and Their Paleoanthropological Implications. Cambridge University Press, pp. 1-27.

2008g - Berna F., Ligouis B., Albert R., Schiegl S., BarYosef O., Dibble H., Conard N. Artioli G., Goldberg P. 2008. High resolution study of paleolithic combustion features: preliminary results from Kebara Cave (Israel), Pech de l'Azé IV (France), and Hohle Fels (Germany). Journal of Archaeological and Anthropological Sciences.

2008f - McPherron S., Dibble H. and Olszweski D. GPS Surveying and On-Site Stone Tool Analysis: Equipping Teams for Landscape Analysis in the Egyptian High Desert. In Layers of Perception, Axel Posluschny, Karsten Lambers, and Irmela Herzog (editors), CD supplement. Bonn: Dr. Rudolf Habelt.

2008e - Gernat T., Shannon J.P. McPherron, H. Dibble, and Jean-Jacques Hublin. An Application of Structured Light Scanning to Documenting Excavated Surfaces and in situ Finds: Examples from the Middle Paleolithic Sites of Jonzac and Roc de Marsal, France. In Layers of Perception, ed. P. Posluschny, K. Lambers, and Irmela Herzog, 51-56. Bonn: Dr. Rudolf Habelt.

2008d - Turq A., H. Dibble, J.-P. Faivre, P. Goldberg, S. McPherron, and D. Sandgathe. "Le Moustérien du Périgord Noir : Quoi de Neuf ?" In Les Sociétés du Paléolithique dans un Grand Sud-Ouest de la France : Nouveau Gisements, Nouveau Résultats, Nouvelles Méthodes. Mémoire XLVII de la Société Préhistorique Française, pp. 83-93.

2008c - Dibble H., L. Shannon, P. McPherron, Deborah I., Olszewski Jennifer, R. Smith, Utsav Schurmans, and Laurent Chiotti. «Prehistoric Abydos: Africa's Gateway to the World» Expedition 50(3):17-22.

2008b - Dibble Harold L, Alain Turq, Shannon P. McPherron, Dennis Sandgathe, Pierre Guibert, JeanChristophe Castel, A. B. Blackwell. Roc de Marsal. Bilan Scientifique 2006: 7-9. Direction Régionale des Affaires Culturelles de l'Aquitaine et Service Régional de l'Archéologie.

2008a - Dibble, H. Non-Anthropological Approaches to Understanding Lithic Artifact and Assemblage Variability. In Archaeological Concepts for the Study of the Cultural Past, edited by A. P. Sullivan III, pp. 85-107. Foundations of Archaeological Inquiry Series. University of Utah Press, Salt Lake City.

2007g - McPherron, S. and Harold L. Dibble "Artifact Orientations from Total Station Proveniences." In The World is in Your Eyes, A. Figueiredo and G. Velho (eds). Tomar: CAA Portugal.

$2007 \mathrm{f}$ - Dibble, H., S. McPherron, T. McPherron. 12V. The SAA Archaeological Record 7:35-41.

2007e - Dibble, H. and S. McPherron. Truncated-Faceted Pieces: Hafting Modification, Retouch, or Cores? In Tools versus Cores Alternative Approaches to Stone Tool Analysis, S. McPherron, editor, pp. 75-90. Newcastle: Cambridge Scholars Publishing.

2007d - Sandgathe, D. and H. Dibble. Excavating a Cave Site. Dig (9): 25-27. 
2007c - Chiotti L., D. Olszewski, H. Dibble, S. McPherron, U. Schurmans, and J. Smith. Paleolithic Abydos Reconstructing Individual Behaviors across the High Desert Landscape. In Z. Hawass and J. Richards, Editors, The Archaeology and Art of Ancient Egypt: essays in honor of David B. O'Connor, Cairo: Supreme Council of Antiquities Press.

2007b - Dibble H., C. Marean and S. McPherron. On the Use of Barcodes in Excavation Projects with Examples from Mossel Bay (South Africa) and Roc de Marsal (France). The SAA Archaeological Record 7:33-38.

2007a - Chase, Philip G., André Debénath, Harold L. Dibble, Shannon P. McPherron, Henry P. Schwarcz, Thomas W. Stafford, Jean-François Tournepiche. New Dates for the Fontéchevade (Charente, France) Homo Remains. Journal of Human Evolution 52-217-221.

2006d - Dibble, H. and S. McPherron. The Missing Mousterian. Current Anthropology 47:777-803.

2006c - Olszewski D.I. and H.L. Dibble. To Be or Not To Be Aurignacian: The Zagros Upper Paleolithic. In Towards a Definition of the Aurignacian, O. Bar-Yosef and J. Zilhao (eds.), p. 355-373. Trabalhos de Arqueologia 45, Lisboa, American School of Prehistoric Research/Instituto Português de Arqueologia.

2006b - Banks W., F. d'Errico., H. Dibble, L. Krishtalka, D. West, D Olszewski, A. T. Peterson, D. Anderson, JC. Gillam, A. Montet-White, M. Crucifix, C. Marean, M-F Sanchez-Goni, B. Wohlfarth, M. Vanhaeran EcoCultural Niche Modeling: New Tools for Reconstructing the Geography and Ecology of Past Human Populations. PaleoAnthropology 2006: 68-83.

2006a - Dibble H., S. McPherron, P. Chase, W. Farrand, A. Debénath. Taphonomy and the Concept of Paleolithic Cultures: The Case of the Tayacian from Fontéchevade PaleoAnthropology 2006:1-21.

2005e - Olszewski, D.I., H.L. Dibble, A. Schurmans, S. McPherron, and J. Smith. High Desert Paleolithic Survey at Abydos (Egypt). Journal of Field Archaeology 30:283-303.

2005d - Dibble, Harold L., T. Raczek, S. McPherron. Excavator bias at the Site of Pech de l'Azé IV, France. Journal of Field Archaeology 30:317-328

2005c - Dibble Harold L., Utsav Schurmans, Radu lovita, and Michael V. McLaughlin. The Measurement and Interpretation of Cortex in Lithic Assemblages. American Antiquity 70(3): 545-560.

2005b - McPherron S., Harold L. Dibble, and Paul Goldberg. Z. Geoarchaeology 20(3):243-262.

2005a - Dibble Harold L., Shannon P. McPherron, and Paul Goldberg. Pech de l'Azé IV. Bilan Scientifique 2003: 22-24. Direction Régionale des Affaires Culturelles de l'Aquitaine et Service Régional de l'Archéologie.
2004 - Dibble Harold L. and Shannon P. McPherron. Pech de I'Azé IV. Bilan Scientifique 2002: 10-20. Direction Régionale des Affaires Culturelles de l'Aquitaine et Service Régional de l'Archéologie.

2003c - McPherron Shannon P. and Harold L. Dibble. "Using Computers in Adverse Field Conditions: Tales from the Egyptian Desert» The SAA Archaeological Record 3(5):28-32.

2003b - Valladas Hélène, Norbert Mercier, Jean-Louis Joron, Shannon McPherron, Harold L.Dibble, and Michel Lenoir «TL Dates for the Middle Paleolithic Site of CombeCapelle Bas, France» Journal of Archaeological Science30:1443-1450.

2003a - Dibble H. and S. McPherron. Pech de l'Azé IV. Bilan Scientifique 2001: 24-30. Direction Régionale des Affaires Culturelles de l'Aquitaine et Service Régional de l'Archéologie.

2002b - Debénath A., P. G. Chase, and H. L. Dibble. A propos d'un poinçon prevenant de la grotte des Fées à Châtelperron. Bulletin de la Société Préhistorique Français 99 :378-379.

2002a - Dibble H. Learning more about Neandertals. Expedition 44:48

2001d - Dibble H. and McPherron, S. Pech de l'Azé IV. Bilan Scientifique 2000: 22-23. Direction Régionale des Affaires Culturelles de l'Aquitaine et Service Régional de l'Archéologie.

2001c - McPherron S., M. Soressi, H. Dibble. Deux nouveaux projets de recherche à Pech de l'Azé (Dordogne, France) Préhistoire du SudOuest 8:11-30.

2001b - Olszewski, D., McPherron, S., Dibble, H., and Soressi, M. Middle Egypt in Prehistory: A Search for the Origins of Modern Human Behavior and Human Dispersal. Expedition 43(2):31-37.

2001a- Dibble H. Middle Paleolithic. Encyclopedia of Prehistory, Vol I: Africa, Plenum Press, pp. 161-177.

2000b - Dibble H. Forward, in Aurignacian Lithic Econonmy: Ecological Perspectives from Southwestern France, by Brooke Blades. Plenum.

2000a - McPherron S. and Dibble, H. The Lithic Assemblages of Pech de l'Azé IV (Dordogne, France). Préhistoire Européenne 15:9-43.

1999c - McPherron S. and Dibble, H. Stone Tool Analysis using Digitized Images: Examples from the Lower and Middle Paleolithic. Lithic Technology 24(1):38-52.

1999b - Debénath A., A. Jelinek, D. Armand, P. Chase, H. Dibble, N. Mercier, J. Renault-Miskovsky, A-M Tillier, $\mathrm{H}$. Valladas and B. Vandermeersch. Nouvelles Fouilles à La Quina (Charente). Gallia Préhistoire 40:29-74. 
1999a - McPherron Shannon P., Philip G. Chase, André Debénath, Harold L. Dibble and Brooks B. Ellwood. The Fontéchevade Fossils: A reanalysis of their archaeological context based on new excavations. American Journal of Physical Anthropology Supplement 28:199.

1998b - Dibble H. Comment on "Quantifying Lithic Curation: An Experimental text of Dibble and Pelcin's original flaketool mass predictor", by Zachary J. Davis and John J. Shea. Journal of Archaeological Science 25:611-613.

1998a - Roth B., and Dibble, H. The Production And Transport of Blanks and Tools at the French Middle Paleolithic Site of Combe-Capelle Bas. American Antiquity 63(1):47-62.

$1997 f$ - Dibble H. et Lenoir, M.. Données Nouvelles sur le Gisement de Combe-Capelle à Saint-Avit-Sénieur (Dordogne). Gallia Préhistoire 39:31-83.

1997e - Dibble H. Platform Variability and Flake Morphology: A Comparison of Experimental and Archaeological Data and Implications for Interpreting Prehistoric Lithic Technological Strategies. Lithic Technology 22(2):150-170

1997d - Dibble H., P. Chase, S. McPherron, and A. Tuffreau, Testing the Reality of a "Living Floor" with Archaeological Data. American Antiquity 62(4):629-651.

1997c - Dibble H. Review of Olduvai Gorge. Volume 5: Excavations in Beds III, IV, and the Masek Beds 19681971, by Mary Leakey with Derek Roe. Journal of Field Archaeology 24(2):255-256.

1997b - Dibble H. Review of Le Trou Magrite Fouilles 19911992 : Résurrection d'un Site Classique en Wallonie, edited by Marcel Otte and Lawrence G. Straus. Journal of Anthropological Research 53(1):95-96.

1997a - Dibble H. and S. McPherron. The Making of Combe-Capelle on CD-ROM. Journal of Field Archaeology 24(1):59-66

1996 - Dibble H. A Reply to Pettitt. Lithics 16: 80-89.

1995p - Dibble H. Biache Saint-Vaast, Level Ila: A comparison of analytical approaches. In Dibble, $\mathrm{H}$. and O. Bar-Yosef. The Definition and Interpretation of Levallois Variability. Prehistory Press, Madison, p. 96-113.

19950 - Bar-Yosef O. and H. Dibble. Preface. The Definition and Interpretation of Levallois Variability. Prehistory Press, Madison. xiii + 502 pp. ix-xiii.

1995n - Lenoir M. and H. Dibble. The Haut de CombeCapelle, or Abri Peyrony. In Dibble, $\mathrm{H}$. and M. Lenoir, The Middle Paleolithic Site of Combe-Capelle Bas (France). University Museum Press, University of Pennsylvania, p. 329-339.

1995m - Dibble H. and M. Lenoir. Summary and Conclusions. In Dibble, $\mathrm{H}$. and $\mathrm{M}$. Lenoir, The Middle Paleolithic Site of Combe-Capelle Bas (France). University Museum Press, University of Pennsylvania, pp. 317-320.
1995I - Dibble H. Raw Material Availability and Intensity of Utilization: A Test of Current Models of Middle Paleolithic Assemblage Variability. In Dibble, $\mathrm{H}$. and M. Lenoir, The Middle Paleolithic Site of Combe-Capelle Bas (France). University Museum Press, University of Pennsylvania, p. 290-315.

1995k - Dibble H., M. Lenoir, and B. Roth. The Use of Raw Materials at Combe-Capelle Bas. In Dibble, $\mathrm{H}$. and M. Lenoir, The Middle Paleolithic Site of Combe-Capelle Bas (France). University Museum Press, University of Pennsylvania, pp. 259-287.

1995j - Dibble H. An Assessment of the Integrity of the Archaeological Assemblages. In Dibble, $\mathrm{H}$. and $\mathrm{M}$. Lenoir, The Middle Paleolithic Site of Combe-Capelle Bas (France). University Museum Press, University of Pennsylvania, pp. 245-257.

1995i - Dibble H. Introduction to Site Formation. In Dibble H. and M. Lenoir, The Middle Paleolithic Site of Combe-Capelle Bas (France). University Museum Press, University of Pennsylvania, pp. 175-178.

1995h - Dibble H. and M. Lenoir. Summary of the Archaeological Sequence. In Dibble, H. and M. Lenoir, The Middle Paleolithic Site of Combe-Capelle Bas (France). University Museum Press, University of Pennsylvania, p. $161-173$

$1995 \mathrm{~g}$ - Roth B., M. Lenoir and H. Dibble. Description of the Lithic Assemblages. In Dibble, $\mathrm{H}$. and $\mathrm{M}$. Lenoir, The Middle Paleolithic Site of Combe-Capelle Bas (France). University Museum Press, University of Pennsylvania, p. 41-159.

$1995 f$ - Dibble H., M. Lenoir, S. Holdaway, B. Roth, and $H$. Sanders-Gray. Techniques of Excavation and Analysis. In Dibble, H. and M. Lenoir, The Middle Paleolithic Site of Combe-Capelle Bas (France). University Museum Press, University of Pennsylvania, p. 27-40.

1995e - Dibble H. and M. Lenoir. The Development of the Research Design for the Current Excavation of CombeCapelle Bas. In Dibble, $\mathrm{H}$. and $\mathrm{M}$. Lenoir, The Middle Paleolithic Site of Combe-Capelle Bas (France). University Museum Press, University of Pennsylvania, pp. 7-26.

1995d - Lenoir, M. and H. Dibble. Overview of the History of Prehistoric Research in the Couze Valley. In Dibble $\mathrm{H}$. and M. Lenoir, The Middle Paleolithic Site of CombeCapelle Bas (France). University Museum Press, University of Pennsylvania, pp. 1-5.

1995c - Dibble H. Middle Paleolithic Scraper Reduction: Background, Clarification, and Review of the Evidence to date. Journal of Archaeological Method and Theory 2:299-368.

1995b - Dibble H. and A. Pelcin. The Effect of Hammer Mass and Velocity on Flake Mass. Journal of Archaeological Science 22:429-439. 
1995a - Tuffreau A., P. Antoine, P. Chase, H. Dibble, B. Ellwood, T. van Kolfschoten, A. Lamotte, M. Laurent, S. McPherron, A.-M. Moigne et A. Munaut. Le Gisement Acheuléen de Cagny-l'Epinette (Somme). Bulletin de la Société Préhistorique Française 92:169-191.

1994d - Dibble H. and M. Lenoir. Fouilles récentes à Combe-Capelle Bas (Dordogne): pourquoi et comment? Bulletin Société dÁnthropologie du Sud-Ouest 29:42-44.

1994c - Chase P., D. Armand, A. Debénath, H. Dibble, and A. Jelinek. Taphonomy and Zooarchaeoogy of a Mousterian Faunal Assemblage from La Quina, Charente, France. Journal of Field Archaeology 21:289-305.

1994b - Dibble H. Review of Making Silent Stones Speak, by K. Schick and N. Toth. American Journal of Physical Anthropology 93:404-5.

1994a - Olszewski D. and H. Dibble. The Zagros Aurignacian. Current Anthropology 35:68-75.

1993e - Dibble H. and O. Bar-Yosef. Definition and Interpretation of Levallois Technology. Evolutionary Anthropology 3:76.

1993d - Dibble H. Le Paléolithique Moyen Récent du Zagros. Bulletin de la Société Préhistorique Française 90(4):307-312.

1993c - Dibble H. and S. Holdaway. The Middle Paleolithic of Warwasi Rockshelter. In The Paleolithic Prehistory of the Zagros-Taurus, edited by Deborah Olszewski and Harold L. Dibble. The University Museum Press, University of Pennsylvania, pp. 75-99..

1993b - Dibble, H. Paleolithic Archaeology: The Search for our Human Heritage. Expedition 34:14-22.

1993a - Dibble, H. and P. Chase. On Mousterian and Natufian Burials in the Near East. Current Anthropology 34:170-172.

1992d - Dibble H. and S. McPherron. Computers and Prehistoric Archaeology. Les Cahiers de la Vallée de la Couze, bulletin 2-3:69-74. CIRPC, Montferrand-duPérigord.

1992c - Dibble H. and N. Rolland. On Assemblage variability in the Middle Paleolithic of Western Europe: History, Perspectives, and a new Synthesis. In The Middle Paleolithic: Adaptation, Behavior, and Variability, edited by Harold L. Dibble and Paul Mellars. The University Museum, University of Pennsylvania, pp. 1-28.

1992b - Debénath A., A. Jelinek, H. Dibble. La Quina. In Neandertal en Poitou- Charentes, edited by A. Debénath and J.-F. Tournepiche, Association Régional des Conservateurs des Musées de Poitou-Charentes, Angoulême, pp. 157-164. 1992a - Chase P. and H. Dibble. Scientific Archaeology and the Origins of Symbolism: A reply to Bednarik. Cambridge Archaeological Review 2(1):43-51.

1991d - Dibble Harold L. Local Raw Material Exploitation and its Effects on Lower and Middle Paleolithic Assemblage Variability. In Montet-White, Anta and Holen, Steve, editor, Raw Material Economies Among Prehistoric HunterGatherers. Lawrence: University of Kansas Publications in Anthropology 19, University of Kansas, pp. 33-48.

1991c - Dibble H. and A. Debénath. Paradigmatic Differences in a Collaborative Research Project. In Pradigmatic Biases in Circum-Mediterranean HunterGatherer Research, edited by G. Clark. University of Pennsylvania Press, pp. 217-226.

1991b - Dibble H. Rebuttal to "On the Validity of Middle Paleolithic Tool Types: A Test Case from the Eastern Sahara», by Angela Close. Journal of Field Archaeology, 264-267.

1991a - Dibble, H. Mousterian Assemblage Variability on an Interregional Scale. In A Quarter Century of Paleoanthropology: Views from the USA, edited by Lawrence Straus. Special issue of Journal of Anthropological Research, 47(2):239-258.

$1990 f$ - Dibble H. «A Personal Perspective on the Computerization of Archaeology.» Bulletin of the Society for American Archaeology 8:9-10.

1990e - Chase P. and H. Dibble. Comment on « Major Issues in the Emergence of Modern Humans ", by P. Mellars. Current Anthropology 31:58-59.

1990d - Dibble H. and P. Chase. Comment on "Symbolism and Modern Human Origins ", by J. M. Lindly and G. A. Clark. Current Anthropology 31:241-243.

1990c - Dibble H. and S. Holdaway. La Paléolithique Moyen de l'Abri de Warwasi et ses rapports avec les Moustériens du Zagros et du Levant. L'Anthropologie, 94:619-642.

1990b - Rolland N. and H. Dibble. A New Synthesis of Middle Paleolithic Assemblage Variability. American Antiquity, 55(3):480-499. Reprinted in Paleoanthropology Annuals, vol. 1, 1990.

1990a - Dibble H., M. Lenoir, J.-P. Texier. Un site préhistorique de la vallée de la Couze. Combe-Capelle à Saint-Avit-Sénieur. Les Cahiers de la Vallée de la Couze 1:32-35. CIRC, Montferrand-du-Périgord.

1989d - Dibble H. Comment on "The Archaeology of Perception: Traces of Depiction and Language ", by I. Davidson and W. Noble. Current Anthropology 30:330331.

1989c - Dibble H. Review of « The Human Uses of Flint and Chert », edited by G. de G. Sieveking and M. Newcomer. American Antiquity 54(2):434-435. 
1989b - Dibble H. The Implications of Stone Tool Types for the Presence of Language during the Middle Paleolithic. In The Human Revolution: Behavioral and Biological Perspectives on the Origins of Modern Humans, Vol. 1, edited by P. Mellars and C. Stringer. Edinburgh University Press, p. 415-432.

1989a - Jelinek A., A. Debénath, and H. Dibble. Preliminary Report on Evidence Related to the Interpretation of Economic and Social Activities of Neanderthals at the Site of La Quina (Charente), France. In L'Homme de Neanderthal, Volume 6, La Subsistance, edited by M. Patou and L. G. Freeman. Etudes et Recherches Archéologiques de l'Université de Liège, No. 33, p. 99-106.

1988d - Dibble H. and S. McPherron. On the Computerization of Archaeological Projects. Journal of Field Archaeology 15(4):431-440.

1988c - Dibble H. The Interpretation of Middle Paleolithic Scraper Reduction Patterns. In L'Homme de Neanderthal, Volume 4, La Technique, edited by J.-Ph. Rigaud, p. 49-58.

1988b - Dibble H. New Excavations at Ice Age Sites. Expedition, vol 29(2):10-11.

1988a - Dibble H. Typological Aspects of Reduction and Intensity of Utilization of Lithic Resources in the French Mousterian. In Upper Pleistocene Prehistory of Western Eurasia, edited by $\mathrm{H}$. Dibble and A. Montet-White. University Museum Monograph 54, University Museum Symposium Series, Vol. 1, Philadelphia, pp. 181-197.

$1987 f$ - Dibble H. The Interpretation of Middle Paleolithic Scraper Morphology. American Antiquity 52:109-117.

1987e - Dibble H. Direct Measurement of Artifact Provenience with an Electronic Theodolite. Journal of Field Archaeology 14:249-254.

1987d - Chase, P. and H. Dibble. Symbolic Behavior in the Middle Paleolithic: A Review of Current Evidence and Interpretations. Journal of Anthropological Archaeology 6:263-296.

1987c - Dibble, H. Comparaisons des Sequences de Reduction des Outils Moustériens de la France et du Proche-Orient. L'Anthropologie, Paris, 91:189-196.

1987b - McPherron S. and H. Dibble. Hardware and Software Complexity in Computerizing Archaeological Projects. Advances in Computer Archaeology, vol 4:25-40.

1987a - Dibble H. Reduction Sequences in the Manufacture of Mousterian Implements of France. In The Pleistocene Old World: Regional Perspectives, O. Soffer, editor, p. 33-45. Plenum Press.

1986b - Dibble H. Description et Historique du site de Combe-Capelle. Bulletin de la Société d'Etudes et de Recherches Préhistoriques Les Eyzies vol. 35:7-11. 1986a - White J. Peter and H. Dibble. Stone tools: Small Scale Variability. In Stone Age Prehistory: Studies in Memory of Charles McBurney, G. Bailey and P. Callow (editors), pp. 47-53. Cambridge University Press.

1985c - Dibble H. Technological Aspects of Flake Variation: A comparison of experimental and prehistoric flake production. American Archeology 5:236-240.

1985b - Dibble H. Raw Material Variability in Levallois Flake Manufacture. Current Anthropology, 26(3):391-393.

1985a - Dibble H. Reply to Lenoir and Witter. Current Anthropology vol. 26(4):519-520.

1984b - Dibble H. Interpreting Typological Variation of Middle Paleolithic Scrapers:Function, Style, or Sequence of Reduction? Journal of Field Archaeology 11:431-436.

1984a - Dibble H. The Mousterian Industry from Bisitun Cave (Iran). Paléorient 10:23-34.

1983 - Dibble H. Variability and Change in the Middle Paleolithic of France and the Near East. In The Mousterian Legacy: Human Biocultural Change in the Upper Pleistocene, E. Trinkaus, editor, pp. 53-71. BAR International Series 264:Oxford.

1982 - Fish, P. and H. Dibble. Comment on «Rethinking the Transition from Middle to Upper Paleolithic», by $\mathrm{R}$. White. Current Anthropology vol. 23(2):182.

1981c - Dibble, H. and J. Whittaker. New Experimental Evidence on the Relation between Percussion Flaking and Flake Variation. Journal of Archaeological Science 8(3):283-296.

1981b - Dibble H. and P. Chase. A New Method of Recording Artifact Shape. American Antiquity 46(1):178-187.

1981a - Dibble H. Technological Strategies of Stone Tool Production at Tabun Cave (Israel), Doctoral Dissertation, University of Arizona, University Microfilms, p. xii + 206.

1980 - Dibble H. and M. Bernard. A Comparative Study of Basic Edge Angle Measurement Techniques American Antiquity 45:857-865.

1976 - Dibble H. Comment on « Gender Differences and the Origin of Language ». Current Anthropology vol. 17(4):744.

\section{Laboratory Project}

2006 - Laboratory for the Study of Ancient Technology, currently investigating flake formation and its application to lithic assemblage technological variability.

\section{Field Projects}

2016 - Pech de l'Azé IV, Layer 8. 
2012 - La Gane (Dordogne, France). Co-director with André Morala, Shannon McPherron, Paul Goldberg, Dennis Sandgathe, and Alain Turq.

2010-2015 - La Ferrassie (Dordogne, France). Co-director with Alain Turq, Shannon McPherron, Dennis Sandgathe, Paul Goldberg, Vera Aldeias, with funding from the Leakey Foundation and National Science Foundation.

2006-2011 - Grotte de Contrebandiers (Smugglers' Cave) Morocco. Co-Director with Abdoujalil el Hajraoui, with funding from the National Science Foundation, Leakey Foundation and National Geographic Society.

2004-2010 - Roc de Marsal (Dordogne, France). Codirector with Shannon McPherron, Dennis Sandgathe and Alain Turq, with funding from Leakey Foundation and National Science Foundation.

2000-2008 - Abydos Survey for Prehistoric Sites (Abydos, Egypt). Co-director with Shannon McPherron, Jennifer Smith, and Deborah Olszewski, with funding from Leakey Foundation, National Science Foundation and private donations. Project results published as a series of articles.

2000-2003 - Pech de l'Azé IV (Dordogne, France). Codirector with Shannon McPherron. Project funded by NSF, with supplemental funding awarded to develop a public website.

1994-1999 - Fontéchevade (Charente, France). Codirector, with André Debénath, Philip Chase, and Shannon McPherron. Funded by NSF. Monograph published by Cambridge University Press

1991-1994 - Cagny-l'Epinette, Cagny-la-Garenne (Somme, France). Co-director with Alain Tuffreau and Philip Chase. Project funded primarily through NSF. Project results published as a series of articles in both American and French journals.

1985-1990 - Combe-Capelle (Dordogne, France). Codirector with Michel Lenoir. Project was funded primarily through NSF. Project results published in several articles in both American and French journals, as a monograph and CD-ROM, and the results also served as the background for an interactive text.

1984-1990 - La Quina (Charente, France). Served as Associate Director, primarily responsible for developing computerized data collection system. Project Directors: Arthur Jelinek and André Debénath.

\section{International Symposia Organized}

2014 - "Women in Archaeology". Philadelphia.

2013 - "Rethinking the Lithics Paradigm III". Philadelphia, PA
2013 - "Rethinking the Lithics Paradigm II". Honolulu, HI.

2013 - "Rethinking the Lithics Paradigm I". Leipzig, Germany.

2012 - "The Emergence of Modern Humans: New Evidence from Contrebandiers Cave (Morocco)", coorganized with Vera Aldeais. SAA, Memphis, TN.

2009 - "Results of New Excavations at the Middle Paleolithic Site of Roc de Marsal. SAA, St. Louis, MO.

2008 - "From the Pecos to the Paleolithic: Papers in honor of Arthur J. Jelinek", co-organized with Deborah Olszewski, Vancouver, BC, Canada.

2005 - "Ecological-Cultural Niche Modeling: Hominin Dispersal and Adaptation during the Pleistocene", coorganized with Francesco D'Errico.

2004 - "The Middle Paleolithic Sites of Pech de l'Azé (Dordogne), France, co-organized with Shannon McPherron and Marie Soressi, Montreal Canada.

2000 - "From Coups-de-Poing to Clovis: Multiple Approaches to Biface Variability", co-organized with Marie Soressi. Philadelphia, PA. Published as Soressi, M. and H. Dibble, From Prehistoric Bifaces to Human Behavior: Multiple Approaches to the study of Bifacial Technologies. The University Museum, University of Pennsylvania.

1993 - «The Definition and Interpretation of Levallois Technology, co-organized with Ofer Bar-Yosef. University Museum, University of Pennsylvania, Philadelphia, PA. Published as Dibble, $\mathrm{H}$. and Ofer Bar-Yosef. The Definition and Interpretation of Levallois Variability. Prehistory Press, Madison, 1995.

1990 - «The Paleolithic Prehistory of the Zagros-Taurus», co-organized with Deborah Olszewski. Las Vegas, Nevada. Published as Olszewski, Deborah and H. Dibble, editors, The Paleolithic Prehistory of the Zagros-Taurus. The University Museum, University of Pennsylvania, 1993.

1989 - «Middle Paleolithic Adaptations in Eurasia», coorganized with Paul Mellars. Atlanta, GA. Published as New Perspectives on the Middle Paleolithic: Adaptations, Behavior and Variability, edited by Harold L. Dibble and Paul Mellars. The University Museum Press, University of Pennsylvania, University Museum Monograph 54, University Museum Symposium Series, Vol. 2, 1992.

1987 - «The Upper Pleistocene Prehistory of Western Eurasia» co-organized with Anta Montet-White. Philadelphia, PA. Published as Dibble, H. and Anta MontetWhite, editors, Upper Pleistocene Prehistory of Western Eurasia. University Museum Monograph 54, University Museum Symposium Series, Vol. 1, Philadelphia. 1988. 